4. Бочковський, А.П. «Людський фактор» та ризик виникнення небезпек: випадковість чи закономірність. [Монографія]. Одеса, Юридична література, 2015. - С. 136.

5. Марфенин Н.Н. Концепџия «устойчивого развития» в развитии / Под общей редакиией: Данилова-Данильяна В.И., Степанова С.А. - М.: Изд-во МНЭПУ, 2002.

6. Бочковський, А.П. Теоретичні аспекти критеріальної оцінки потенціалу ефективності системи управління охороною прачі [Текст] /А.П. Бочковський// Вісник Львівського державного університету безпеки життєдіяльності. 2016. - №12. - C. 100-107. DOI: 10.13140/RG.2.1.2413.5444.

7. Бочковський, А.П. Формалізація системи автоматизованого контролю і підвищення безпеки виробництв [Текст] /А.П. Бочковський, Н.Ю. Сапожнікова// Вісник Львівського державного університету безпеки життєдіяльності. - 2017. - №15. - C. 114-123. DOI: 10.13140/RG.2.2.11062.29762.

8. Урсул, А.Д. Обеспечение безопасности через устойчивое развитие / А.Д. Урсул // Безопасность Евразии. - 2001. № 1. - C. 443-456.

9. Бочковський, А.П. Пріоритетні напрямки удосконалення системи управління охороною праці на підприємствах [Текст] /А.П. Бочковський// Зернові продукти і комбікорми. - 2014. - № 2(54). - C. 11-16. doi: 10.13140/RG.2.1.2255.8483

10. Вернадский В.И. Научная мысль как планетарное явление. М., Наука, 1991. С. 241.

11. Бочковський, А. П. Науково-практичні аспекти мінімізаиї̈ ризиків виникнення професійних небезпек [Текст] / А. П. Бочковський, Н.Ю. Сапожнікова // Екологічна безпека та збалансоване ресурсокористування, 2017. - № 2 (16) - C. 92-101 DOI:10.13140/RG.2.2.36574.13124.

12. Доповідь Міжнародної організаиії праці [Електронний ресурс] / Режим достуny: http://www.ilo.org.

13. Державна служба статистики України [Електронний ресурс] / Pежим доступу: http://www.ukrstat.gov.ua. Надійшла 21.08.2018. До друку 29.08.2018. Рецензія 29.08.2018 Адреса для переписки: вул. Канатна, 112, м. Одеса, 65039

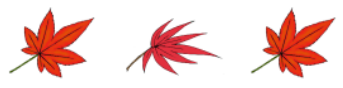

УДК 664.314

С.П. КРАСВСЬКА*, аспірант, Н.О. СТЕЦЕНКО*, канд. хім. наук, доценТ Г.М. БАНДУРЕНКО**, канд. техн. наук, доцент

*Національний університет харчових технологій

**Київський кооперативний інститут бізнесу і права

\title{
ОЦІНЮВАННЯ ЯКОСТІ БІЛКА НАСІННЯ ЛЬОНУ МЕTОДОМ DIAAS
}

\section{Анотація}

Розробка нових харчових продуктів та раціонів підвищеної біологічної иінності, а також удосконалення вже існуючих виробів неможливо без наявності точних критеріїв оцінки отриманого результату. Білкова складова в харчуванні переважної більшості людей є найбільш дефіцитною, тому оцінці якості білкового компонента їжі приділяється особлива увага. Сьогодні існуе досить багато методик оцінки біологічної цінності харчових продуктів. Хоча медико-клінічні дослідження забезпечують отримання більш точних результатів, однак вимагають значних фінансових затрат.

Для ефективного удосконалення рецептур існуючих виробів і розробки нових продуктів з підвищеною біологічною цінністю необхідно мати точні методики оцінки якості білка, які не вимагають значних витрат часу $і$ коштів.

В роботі наведені необхідні формули та дані для використання методики DIAAS. Hа прикладі білка насіння льону показано зміни амінокислотного складу до і після його пророщування, а також наведено розрахунки показника DIAAS

Насіння льону (Linum иsitatissimum) відносять до білково-олійних культур, оскільки в своєму складі (залежно від сорту та умов вирощування) містить 17-30\% білків та 32-50\% жирів. Білок насіння льону, представлений альбумінами $i$ глобулінами, має повний склад незамінних амінокислот (НАК), схожсий до складу соєвих білків, які вважаються найбільш поживними протеїнами рослинного походження. Пророчування льону дозволяе використовувати всі анатомічні частини насінини у технологіях продуктів оздоровчого призначення, адже у процесі пророщування помякшуються оболонки $i$ з'являється приємний солодкий присмак. Пророщування веде до деградаиії антихарчових речовин (фітинова кислота) та появі нових фізіологічно активних речовин (вітаміну $C$, токоферолів).

У статті подано опис нової методики DIAAS (digestible indispensable amino acid score - укр. амінокислотне число незамінних амінокислот з урахуванням їх засвоюваності), яка рекомендована Продовольчою та Сільськогосподарською Організацією Об'єднаних Націй (ФАО) з 2013 року після Міжнародного симпозіуму “Харчові білки для здоров'я людини”. На симпозіумі визнано, щзо амінокислоти слід розглядати як окремі поживні речовини і взявши до уваги зростаючий масив даних щодо їх істинної засвоюваності, було рекомендовано поступовий перехід на методику розрахунку біологічної иінності продуктів і раціонів з урахуванням біологічної доступності окремих амінокислот.

Нова методика DIAAS дозволяс кількісно оцінити засвоюваність кожної амінокислоти окремо з білка продукту. Перетравлення незамінної амінокислоти повинно базуватися на справжній засвоюваності ілеї (тобто визначається наприкінці тонкої кишки) кожної амінокислоти, яка визначається у продукті для людини, але якщо це неможливо, слід використовувати значення засвоюваності незамінної амінокислоти у продукті для зростаючої свині або для зростаючого щура.

Методика може бути корисною при визначенні біологічної цүінності нових видів сировини та конструюванні нових функиіональних харчових продуктів.

Ключові слова: льон, пророщування, DIAAS, якість білка, незамінні амінокислоти, біологічна цінність, функціональне харчування. 


\section{Вступ}

Біологічна цінність продукту - це показник, призначений для визначення ступеня засвоєння в організмі людини білка з харчового продукту. Біологічна цінність білка з 1971 року визначалась за допомогою розрахунку скору незамінних амінокислот продукту. Однак подальше вдосконалення методик медико-біологічних досліджень і накопичення статистичного матеріалу клінічних аналізів вказали на невідповідність подібної оцінки реальним фізіологічним потребам організму людини. Особливо це стосувалося рослинної сировини і продуктів, які пройшли тривалу технологічну обробку. Оскільки на той час вже було відомо, що зміни в молекулі білка під час приготування їжі, а також наявність супутніх антиживильних речовин можуть істотно впливати на засвоюваність білкових речовин. Учасниками наступних Консультативних зборів експертів ФАО / ВОО3, які пройшли в 1989 році, була запропонована методика розрахунку амінокислотного числа з урахуванням засвоюваності - PDCAAS (protein digestibility corrected amino acid score - укр. амінокислотне число 3 поправкою на засвоюваність белка) [1.] Хоча результати, отримані відповідно до цієї методики, були значно ближче до реальних медико-клінічних показників, певна різниця все ж таки зберігалася. Для пояснення цього факту було вивчено біологічну доступність незамінних амінокислот в різних харчових продуктах. Отримані результати показали, що у більшості видів сировини і готових виробах жодна 3 амінокислот не засвоюється повністю. Необхідність врахування цього явища викликала потреба внести зміни в методику розрахунку PDCAAS. Після Міжнародного симпозіуму "Харчові білки для здоров'я людини”, який відбувся в Новій Зеландії в березні 2011 року, у січні 2013 року Продовольча та сільськогосподарська організація (ФАО) Організації Об'єднаних Націй випустила нову доповідь: “Дієтична оцінка якості білка в харчуванні людини”. Основна рекомендація експертів стосується нового передового методу оцінки якості харчових білків 3 більшою точністю. У доповіді ФАО рекомендує новий метод DIAAS (digestible indispensable amino acid score - укр. амінокислотне число незамінних амінокислот 3 урахуванням їх засвоюваності). Визнавши, що амінокислоти слід розглядати як окремі поживні речовини і взявши до уваги зростаючий масив даних щодо їх істинної засвоюваності, було рекомендовано поступовий перехід на методику розрахунку біологічної цінності продуктів і раціонів з урахуванням біологічної доступності окремих амінокислот - DIAAS.[2]

Білки відіграють багато важливих функцій у людському здоров'ї та добробуті, і коли з'являються нові методи оцінки їхньої харчової якості, технологічні прийоми конструювання продуктів та відповідний рівень їх споживання мають бути переглянуті. Для ефективного удосконалення рецептур існуючих виробів і розробки нових продуктів 3 підвищеною біологічною цінністю необхідно мати точні методики оцінки якості білка, які не вимагають значних витрат часу $\mathrm{i}$ коштів. Створення високоякісних продуктів підвищеної харчової цінності - актуальна задача сьогодення. Зважаючи на сучасні екологічні умови та ритм життя, раціон харчування повинен містити достатню кількість природних біологічно активних речовин (БАР), необхідну для підтримання рівноваги метаболізму. Тому, актуальним $є$ розроблення нових продуктів спеціального призначення, які б органічно поєднували у своєму складі різні групи БАР. Велика увага приділяється білковому збагаченню продуктів, зокрема наявністю у ньому вільних амінокислот. Оскільки, білкова складова в харчуванні багатьох людей є найбільш дефіцитною, велика увага у визначенні харчової цінності приділяється саме амінокислотному скору. Працюючи над розширенням асортименту спеціалізованих продуктів, вчені багатьох країн проводять пошук нових дешевих джерел повноцінних білків.

Продовольча білкова проблема як у глобальному, так і національному масштабах залишається найбільш актуальною , досить складною. Актуальність розв'язання ії̈ зростає не тільки у зв'язку з щорічним ростом чисельності населення на 75 млн чоловік, а й із зростаючими вимогами медичної науки щодо якості харч ування. Йдеться про доступність білковмісних продуктів харчування перш за все, для найменш захищених категорій нас елення. Жодна країна у світі ще не розв 'язала продовольчу білкову проблему в повному обсязі та асорти менті. У світі 980 млн людей голодає або недоїдає . Якщо прийняти середню норму споживання білка однією людиною за 100 г/добу (з коливаннями від 70 до 120 г і більше залежно від віку, роду занять і ін.), то річна потреба в ньому становитиме 36,5 кг. Фактичне споживання білка однією людиною складало : у світі - 27,5 кг (75,3\% від норми), в країнах Північної Америки - 36,9 кг $(101,1 \%)$, Свропи - 36,6 кг (100,3\%), Океанії і Австралії - 34,8 кг (95,3\%), Південної Америки - 28,1 кг (77\%), Азії - 25,5 кг $(69,9 \%)$, Африки - 22,3 кг (61,1\%). Дефіцит білка в харчуванні населення у середньому у світі становив 56,1 млн т, або 25\%, в Україні - 255 тис.т. [3]

Білково-олійним культурам належить провідна роль в процесі розвитку, як сільського господарства, так i харчової промисловості загалом. Справа в тому, що білково-олійні культури (соняшник, рапс, льон та ін.) є дешевою і доступною сировиною [5]. Традиційно їх роль полягає в отриманні рослинних олій, але хімічний склад зумовлює використання білково-олійних культур для створення продуктів з покращеною біологічно цінністю. Льондовгунець (Linum usitatissimum) - однорічна рослина родини льонових. Насіння льону характеризується високою харчовою цінністю. Залежно від сорту вміст вологи в ньому може коливатися в межах 7-9\%, кількість жирів - 32-47 \%; білків - 17-28\%. Порівняно 3 іншою рослинною сировиною, льон містить найбільшу кількість ненасичених жирних кислот, включаючи альфа-ліноленову жирну кислоту (родина $\omega 3$ ). Білок насіння льону, представлений альбумінами i глобулінами, має повний склад незамінних амінокислот (НАК), схожий до складу 
соєвих білків, які вважаються найбільш поживними протеїнами рослинного походження. Харчова цінність білка 3 насіння льону за бальною оцінкою (казеїн прийнятий за 100) оцінюється в 92 одиниці [7].

Відповідно до рекомендацій експертів ФАО, щоб претендувати на класифікацію"джерело" білка, їжа повинна відповідати наступним критеріям: містити $10 \%$ білка на 100 г сухої речовини або 5\% білка на 100 мл рідини, або 5\% білка на 100 ккал) [2].

Рекомендований вміст амінокислот у білку для дієтичної оцінки його якості для різних вікових груп наведено в табл. 1.

Якісне оцінювання білків дає можливість оцінити його біодоступність, тобто частку амінокислот, які можуть поглинатися з їжі та засвоюватися організмом. Це відносна величина, яка допомагає визначити здатність харчових білків та продуктів забезпечити потреби організму необхідними амінокислотами та азотом. Співвідношення між харчуванням та потребами людини в білках є життєво важливим для підтримки здоров'я та благополуччя так як пов'язано 3 такими потребами, як ріст, вагітність, період лактації, хвороби та відновлення. Сьогодні існуе досить багато методик оцінки біологічної цінності харчових продуктів. Медикоклінічні дослідження забезпечують найбільш точні результати, але вони вимагають значних витрат коштів і часу. Тому, світові вчені віддають перевагу сучасному розрахунковому методу DIAAS.

Величина DIAAS потрібна для характеристики якості білка продукту: при значенні DIAAS 100\% та більше досліджуваний продукт вважається "відмінним" джерелом білка; 75-99\% - "хорошим" джерелом; 74\% та менше - “невисоким" джерелом білка [6].

Мета роботи - дати оцінку біологічної цінності білка зерна льону до та після пророщування методом DIAAS та ознайомлення широкого кола науковців 3 новою методикою оцінки якості білка. Завдання дослідження - розрахувати значення DIAAS для зерна льону до та після його пророщування.

Матеріали, методика і методи досліджень. Для досліджень використовували насіння льону, поширеного у Київській області, сорту "Вручий”.

Методика виконання роботи. Насіння льону очищають від пошкоджених екземплярів, пилу, бруду та інших сторонніх домішок. Насіння замочують та пророщують до появи паростків довжиною 1-5мм згідно відповідних режимів [4]. Після цього насіння піддають аналізу за методами, наведеними нижче.
Амінокислотний склад досліджених зразків аналізували методом іонообмінної хроматографії (Llames and Fontaine, 1994). Вміст амінокислот після гідролізу з $6 \mathrm{M} \mathrm{HCl}$ (для визначення триптофану застосовується лужний гідроліз) визначали за допомогою автоматичного аналізатора АA (AАA Т339, Прага, Чехія). Для того, щоб розрахувати кількість амінокислот у досліджуваному зразку, попередньо до автоматичного аналізатора амінокислот вносять стандартну суміш амінокислот із відомою концентрацією кожної амінокислоти. На хроматограмі розраховують площу піка кожної амінокислоти. Амінокислотна композиція виражається у відсотках від загального білка.

Оцінка засвоюваності незамінних амінокислот DIAAS (The digestible indispensable amino acid score - укр. амінокислотне число незамінних амінокислот 3 урахуванням їх засвоюваності score) $\epsilon$ рекомендованим методом оцінки якості білка для регуляторних цілей [2].

Оцінку засвоюваності незамінних амінокислот ( DIAAS) для харчових продуктів або харчових інгредієнтів розраховують за допомогою формули:

DIAAS $=(\text { HAK пр/НAKст })^{*} \mathrm{SID}$

де SID (standardized ileal amino acid digestibility) - стандартизоване значення перетравлення незамінної амінокислоти продукту, визначається наприкінці тонкої кишки;

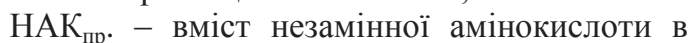
продукті;

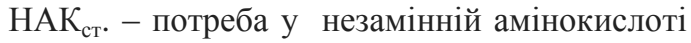
для різних вікових груп згідно рекомендацій ФАО / ВОО3 (відповідно до табл.1).

\section{Результати та їх обговорення.}

Аналізуючи потенційні джерела сировини для створення повноцінних високоякісних продуктів харчування увагу до себе привертає насіння льону. Сьогодні насіння льону використовується як сировина для одержання олій, шротів, а також як біологічно-активна добавка для збагачення хлібобулочних, кисломолочних, м'ясних та рибних продуктів. Фізико-хімічний склад насіння льону дає можливість прогнозувати перспективи використання продуктів переробки льону у функціональному харчуванні.

Для досліджень було обрано сорт льону “Вручий”, який вирощують в більшості областей України. Цей сорт характеризується високою врожайністю, морозо- та засухостійкістю, а також стійкістю до різних захворювань. Насіння льону сорту “Вручий” на 100 г продукту містить 24 г білка, 34 г жирів та 8,6 \% вологи.

Таблиця 1 - Рекомендований вміст амінокислот у білку для різних вікових груп (мг/2)

\begin{tabular}{|l|c|c|c|c|c|c|c|c|c|}
\hline & His & Ile & Leu & Lys & SAA & AAA & Thr & Trp & Val \\
\hline Немовлята & 21 & 55 & 96 & 69 & 33 & 94 & 44 & 17 & 55 \\
\hline Діти (6 міс. - 3 роки) & 20 & 32 & 66 & 57 & 27 & 52 & 31 & 8,5 & 43 \\
\hline Старші діти, підлітки, дорослі & 16 & 30 & 61 & 48 & 23 & 41 & 25 & 6,6 & 40 \\
\hline
\end{tabular}

* His - гістидин, Ile - ізолейцин, Leu - лейцин, Lys - лізин, Thr - треонін, Trp - триптофан,Val - валін,

SAA - сульфоровмісні амінокислоти; АAA - ароматичні амінокислоти. 
Таблиця 2 - Порівняльний амінокислотний склад насіння льону до та після пророщування, мг/100 г продукту

\begin{tabular}{|c|c|c|c|}
\hline \multirow{2}{*}{ Назва амінокислоти } & \multicolumn{3}{|c|}{$\begin{array}{c}\text { Величина показника для насіння льону } \\
\text { у перерахунку на суху речовину, мг/100г }\end{array}$} \\
\hline & $\begin{array}{c}\text { до } \\
\text { проро- } \\
\text { щування }\end{array}$ & $\begin{array}{c}\text { після } \\
\text { проро- } \\
\text { щування }\end{array}$ & $\begin{array}{c}\text { Відношення величини показників } \\
\text { пророщеного насіння льону } \\
\text { до непророщеного, \% }\end{array}$ \\
\hline Білок, г & 26,25 & 33,5 & 127,62 \\
\hline Гістидин (His) & 0,339 & 0,407 & 120,06 \\
\hline Ізолейцин (Ile) & 0,481 & 0,644 & 133,89 \\
\hline Лейцин (Leu) & 1,104 & 1,485 & 134,51 \\
\hline Лізин (Lys) & 0,70 & 1,026 & 146,57 \\
\hline Треонін (Thr) & 0,658 & 0,915 & 139,06 \\
\hline Триптофан (Trp) & 0,149 & 0,209 & 140,27 \\
\hline Валін (Val) & 0,626 & 0,865 & 138,18 \\
\hline $\begin{array}{l}\text { Сульфоровмісні } \\
\text { амінокислоти (SAA)* }\end{array}$ & 0,532 & 0,649 & 121,99 \\
\hline $\begin{array}{l}\text { Ароматичні } \\
\text { амінокислоти (ААA)* }\end{array}$ & 1,253 & 1,87 & 149,24 \\
\hline
\end{tabular}

*SAA (Метіонін+цистеїн), ААА (Фенілаланін+тирозин)

Оскільки, вміст білка складає понад 20\% від загального складу нутрієнтів, насіння льону можна віднести до потенційного джерела білка. Оскільки насіння льону у натуральному вигляді $\epsilon$ досить стійким до травних ферментів, збільшити його біодоступність можна шляхом пророщування та активування власних ферментних систем. При цьому визначали амінокислотний склад насіння льону до та після пророщування. При цьому вологість насіння зростала 3 8,6\% до $46 \%$. Для порівняння отриманих результатів всі розрахунки проводили на абсолютно суху речовину (табл. 2).

3 табл. 2 видно, що вміст амінокислот у пророщеному насінні льону зріс порівняно 3 вихідною сировиною. Приріст амінокислот у пророщеному насінні льону коливається у межах 20-49\%, що свідчить про покращення біохімічного складу.

Дані розрахунки також вказують на те, що лімітуючою амінокислотою у подрібненому і пророщеному насінні льону $\epsilon$ лізин. При конструюванні нових продуктів харчування підвищеної біологічної цінності на основі насіння льону слід враховувати лімітування за лізином і в рецептурах використовувати інгредієнти з підвищеним вмістом цієї амінокислоти (наприклад соя, сироватковий білок).

Таблиця 3 - Розрахунок показника DIAAS насіння льону для категорії стариі діти, підлітки, дорослі

\begin{tabular}{|c|c|c|c|c|c|c|c|}
\hline \multirow[t]{2}{*}{ Назва АК } & \multirow{2}{*}{ SID } & \multirow{2}{*}{$\mathrm{AK}^{*}$} & \multicolumn{2}{|c|}{$\begin{array}{c}\text { Вміст АК мг/1г білка у зерні } \\
\text { льону }\end{array}$} & \multicolumn{2}{|c|}{$\begin{array}{l}\text { Величина показника DIAAS } \\
\text { для зерна льону, мг/1г білка }\end{array}$} & \multirow{2}{*}{$\begin{array}{c}\text { Співвідношенн } \\
\text { я DIAAS до та } \\
\text { після пророщу- } \\
\text { вання }\end{array}$} \\
\hline & & & $\begin{array}{c}\text { до } \\
\text { пророщування }\end{array}$ & $\begin{array}{c}\text { після } \\
\text { пророщування }\end{array}$ & $\begin{array}{c}\text { до } \\
\text { пророщування }\end{array}$ & $\begin{array}{c}\text { після } \\
\text { пророщування }\end{array}$ & \\
\hline Гістидин (His) & 76,4 & 16 & 12,9 & 12,2 & 61,60 & 58,26 & 94,57 \\
\hline Ізолейцин (Ile) & 82,3 & 30 & 18,3 & 19,2 & 50,20 & 52,67 & 104,92 \\
\hline Лейцин (Leu) & 80,6 & 61 & 42 & 44,3 & 55,50 & 58,53 & 105,48 \\
\hline Лізин (Lys) & 73,9 & 48 & 26,7 & 30,6 & 41,11 & 47,11 & 114,61 \\
\hline Треонін (Thr) & 73,5 & 25 & 25 & 27,3 & 73,50 & 80,26 & 109,20 \\
\hline Триптофан (Trp) & 70,5 & 6,6 & 5,7 & 6,2 & 60,89 & 66,23 & 108,77 \\
\hline Валін (Val) & 79,8 & 40 & 23,8 & 25,8 & 47,48 & 51,47 & 108,40 \\
\hline $\begin{array}{l}\text { Сульфоровмісні } \\
\text { амінокислоти } \\
\text { (SAA) }\end{array}$ & 77,6 & 23 & 20,3 & 19,4 & 68,49 & 65,45 & 95,57 \\
\hline $\begin{array}{l}\text { Ароматичні } \\
\text { амінокислоти } \\
\text { (ААА) }\end{array}$ & 84,7 & 41 & 47,7 & 55,8 & 98,54 & 115,27 & 116,98 \\
\hline
\end{tabular}

*АК - Рекомендований вміст амінокислот у білку для дієтичної оцінки його якості для старрших дітей, підлітків та дорослих (див. Табл.1) 
Далі розрахували показник засвоюваності білка (DIAAS) насіння льону при його використанні для дітей старшого віку, підлітків та дорослих, результати наведені у табл. 3 .

Отже, величина DIAAS (Lys) для білка зерна льону до та після пророщування дорівнює 41,11\% та 47,11\% відповідно. Показник DIAAS після пророщування збільшився на 114,6\%. Така зміна свідчить про те, що біологічна цінність білка після пророщування підвищилась. Розраховане значення DIAAS(Lys) для зерна льону до та після пророщування нижче 74\%, що свідчить про потребу комбінування насіння льону 3 іншими інгредієнтами 3 вищим вмістом лізину (сироватковий білок, соя, кисломолочні продукти) при конструюванні нових фцнкціональних продуктів харчування.

\section{ЛITЕРАТУРА}

1. Protein quality evaluation: report of the Joint FAO/WHO Expert Consultation, Rome [Электронный pecypc]: FAO, 1991. 66 p. Режим доступа: http://apps.who.int/iris/bitstream/10665/38133/1/9251030979_eng.pdf (дата обращения 26.04.2017).

2. FAO/WHO, (2013). Dietary protein quality evaluation in human nutrition Report of an FAO Expert Consultation FAO Food and nutrition 92, Rome, Italy 2013.

3. Бабич А.О., Бабич-Побережна А.А. Світові ресурси рослинного білка. // Селекиія і насінництво. -2008. - Випуск 96. C.215-222.

4. Патент України на винахід UA 95081 C2, A23L 1/0526 (2006.1) A23L 1/172 (2006.01).Вільні від клейковини паростки льону та ї побічний прдукт, а також їх виробнищтво та застосування. / Феглейн Ферени НU, БІОГРІН А/C DK. № а200803668; заявл. 06.09.2005; опубл. 11.07.2011. - Бюл. № 13/2011.

5. М.В. Обозная, Ф.В. Периевой, Л.3. Шильман. Перспективы пременения растительных белковых концентратов масличных культур в кондитерской отрасли. // Технология и продукты здорового питания 14 : материаль Межд. VIII науч.-практ. конф., 227 ноября 14 г. : зб. науч. тр. Саратов : ФГБОУ ВПО «Саратовский ГАУ».

6. L. Eastwood and P. Leterme, 2010. Nutritional value of flaxseed meal for swine and its effects on the fatty acid profile of the carcass. Journal of animal science.

7. Зубиов В.А., Осипова Л.Л., Лебедева Т.И. Льняное семья его состав и свойства.// Рос. хим. ж. (Ж. Рос. хим. об-ва им. Д. И. Менделеева), 2002, m. XLVI, No2. - C.14-16.

8. Самоченко О.Н., Маркучева М.А. Пророщеное зерно - перспективное сырье для разработки новых видов изделий.//Новый университет. Международный научный журнал. - 2015. - №7-8. - C.27-32.

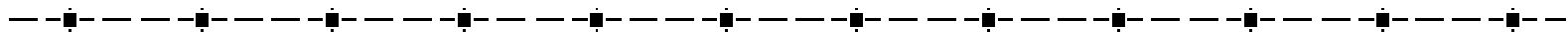

\section{THE DETERMINATION PROTEIN QUALITY BY METHOD DIAAS}

\section{Abstract}

To improve the recipes of existing products and develop new products with increased biological value effectively is necessary to have precise methods for protein quality evaluating. The article describes the DIAAS (digestible indispensable amino acid score) calculation method and provides the necessary data for its use. DIAAS has been adopted internationally as the most suitable method for routine evaluation of protein quality of foods by the Food and Agriculture Organization/World Health Organization. The DIAAS is based on the relative digestible content of the indispensable amino acids (IAAs) and the amino acid requirement pattern. Factors involved in calculation of the DIAAS include: use of the content and profile of IAAs as the basis for quality; methods for determination of the protein and amino acid content of the protein source; accuracy of individual requirement values for IAAs; normalization of IAA requirements by the estimated average requirement for protein; and basing the DIAAS on the true ileal digestibility of each IAA in the test protein. This review outlines the rationale for including each of these factors in the calculation of the DIAAS and describes associated potential errors.

This study aimed to evaluate the aminoacids changes caused by germination. Amino acids are an important component of food. They serve as "building blocks" that make up proteins. Protein deficiency in the body leads to disruption of its normal operation-loss of memory and mental relaxation opportunities, reduce the body's resistance. The effectiveness of the use of protein by the body is determined by two parameters: its balance on the content of essential amino acids and the digestible (dietary) indispensable amino acid score. We used DIAAS for protein quality evaluation in flaxseed and germination flaxseed.

Flaxseeds (Linum usitatissimum) are believed to be protein and oleaginous cultures, since they contain 17-30\% proteins and $32-50 \%$ fats depending on the variety and conditions of cultivation. The flax seed protein, represented by albumins and globulins, has the full composition of essential amino acids (IAA), which is similar to the composition of soy proteins, which are considered to be the most nutritious proteins of vegetable origin. Germination of flax allows to use all the anatomical parts of the seed in the technology of health products, as the germinating process softens the shells and a pleasant sweet taste appears. Germination leads to the degradation of anti-nutrients (phytic acid) and the emergence of new physiologically active substances (vitamin C, tocopherols). 
The researches allow provide increasing of a reliability degree of the estimation of biological value both already existing food products and improved ones.

Key words: flax, germination, DIAAS, sprouts, amino acid, protein quality, biological value, functional food.

\section{REFERENCES}

1. Protein quality evaluation: report of the Joint FAO/WHO Expert Consultation, Rome[Electronic resource]: FAO, 1991. - 66 p. Access mode: http://apps.who.int/iris/bitstream/10665/38133/1/9251030979_eng.pdf(дата обращения 26.04.2017).

2. FAO/WHO, (2013). Dietary protein quality evaluation in human nutrition Report of an FAO Expert Consultation FAO Food and nutrition 92, Rome, Italy 2013.

3. A. Babich, A. Babich-Poberezhnaya AA World resources of vegetable protein // Breeding and seed production. -2008 - Issue $96 .-$ P.215-222.

4. Patent of Ukraine for invention UA 95081 C2, A23L 1/0526 (2006.1) A23L 1/172 (2006.01). Free gluten-free flaxseed germs and their by-products, as well as their production and application. / Feglein Ferents HU, BIOGRIN A / S DK. - № a200803668; Declared 06.09.2005; published on 07/11/2011. - Bulletin No. 13/2011.

5. M. Oboznaya, F. Perceive, L. Shilman Prospects for the replacement of vegetable protein concentrates of oilseeds in the confectionery industry. // Technology and products of healthy nutrition 14: Materials Int. VIII scientific practice. Conf., 2 November 27, 14: Collection of scientific works of Saratov: FGBOOU VPO "Saratov GAU".

6. L. Eastwood and P. Leterme, 2010. Nutritional value of flaxseed meal for swine and its effects on the fatty acid profile of the carcass. Journal of animal science.

7. V. Zubtsov, L. Osipova, T. Lebedeva. Flax seeds its composition and properties.// Ross. chem mag. (Zh. Russian Chemical Society named after DI I. Mendeleev), 2002, vol. XLVI, No.2. - P.14-16.

8. O. Samochenko, M. Markucheva. Sprouted grain is a promising raw material for the development of new types of products. // New University. International scientific journal. - 2015. - № 7-8. - P.27-32.

Надійшла 25.06.2018. До друку 03.08.2018. Рецензія 03.08.2018

Адреса для переписки: вул. Канатна, 112, м. Одеса, 65039

Д.О.ЖИГУНОВ, д-р техн. наук, доцент, О.С. ВОЛОШЕНКО, канд. техн. наук, доцент,

Н.В. ХОРЕНЖИЙ, канд. техн. наук, доцент

Одеська національна академія харчових технологій, м. Одеса

\section{ПОРІВНЯЛЬНЕ ДОСЛІДЖЕННЯ ПОКАЗНИКІВ ЯКОСТІ ЦІЛЬНОЗЕРНОВОГО ПШЕНИЧНОГО ТА СПЕЛЬТОВОГО БОРОШНА ВІТЧИЗНЯНОГО ВИРОБНИЦТВА}

\footnotetext{
Анотація

Стаття присвячена обтрунтуванню необхідності розщирення асортименту борошняної продукції та підвищення іï харчової і біологічної иінності за рахунок виробництва иільнозернового пшеничного борошна.

У статі описані основні завдання та проблеми, щуо стоять перед сучасною зернопереробною промисловістю. Розглянуто переваги иільнозернового борошна, зокрема його підвищена біологічна иінність. Однак, иільнозернове борошно, отримане за різними технологіями виробництва, істотно відрізняється за показниками якості. Здійснено огляд наукових праць, спрямованих на аналіз існуючих в світі вимог на ией вид борочна. Стандарти України на циільнозернове пшеничне борошно на сьогоднішній день відсутні. ГСТУ 46.004-99 «Борошно пшеничне. Технічні умови» розповсюджуються тільки на борошно сортове та оббивне, проте виробники його виготовляють.

Метою роботи було дослідження показників якості иільнозернового пшеничного борошна, яке виробляється 6 Украӥні. У якості об'єкту досліджень використовували (за власною назвою виробника) борочно иільнозернове жорнового помелу пшеничне (обойне), борошно пшеничне обойного сорту, борошно иільнозернове жорнового помелу зі спельти (обойне), борошно иільнозернове жорнового помелу зі спельти, борошно пшеничне грубого помелу органічне, борочно пшеничне иільнозернове, борошно пшеничне особливе грубого помелу, борошно жорнове пшеничне цільнозернове, борошно цільнозернове пшеничне грубого помелу, яке було вироблено на вітчизняних підприємствах.

Вологість усіх зразків цільнозернового борошна не перевищувала 15,0%, щчо відповідає вимогам до пшеничного борошна. Зольність досліджуваних зразків иільнозернового борошна вітчизняного виробництва знаходилась у межах 1,12-1,58 \%. Судячи з показників зольності та крупності ряд виробників при його виробництві дотримуються принципу майже 100-відсоткового потрапляння усіх анатомічних складових зерна у иільнозернове борошно, але при иьому крупність борочна може бути на рівні крупності оббивного борочна, або істотно від нього відрізняться. Випечений хліб відрізнявся розвиненою, рівномірною пористістю, гладкою, без бічних підривів поверхнею скоринки, мав приємний смак і аромат.

Дослідження технологічних, хлібопекарських показників якості иільнозернового пшеничного та спельтового борошна вітчизняного виробництва показало зовсім різні кінщеві результати, щуо обумовлено різними технологічними підходами та відсутністю загальної нормативної документачії.

Доведено, щзо для поліпшення споживчих властивостей та підвищення конкурентоспроможності иільнозернового хліба необхідно встановити конкретні вимоги до якості иільнозернового борошна та дослідити їх вплив на хлібопекарські
} 